\title{
Very short term dehydroepiandrosterone treatment in female adrenal failure: impact on carbohydrate, lipid and protein metabolism
}

Jens Juel Christiansen, Claus Højbjerg Gravholt, Sanne Fisker, Niels Møller, Marianne Andersen ${ }^{1}$, Birgit Svenstrup ${ }^{2}$, Paul Bennett ${ }^{2}$, Per Ivarsen ${ }^{3}$, Jens Sandahl Christiansen and Jens Otto Lunde Jørgensen

Medical Department M, Århus Sygehus, Århus University Hospital, Århus, Denmark, ${ }^{1}$ Department of Endocrinology, Odense University Hospital, Odense, Denmark, ${ }^{2}$ Statens Serum Institut, Copenhagen, Denmark, and ${ }^{3}$ Institute of Experimental Clinical Research, Arhus University, Århus, Denmark

(Correspondence should be addressed to C H Gravholt, Medical Department M, Århus Sygehus, Århus University Hospital, DK 8000 C, Denmark; Email: ch.gravholt@dadlnet.dk)

\begin{abstract}
Objective: In female adrenal insufficiency, dehydroepiandrosterone (DHEA) secretion is impaired and circulating androgen levels are severely reduced. We wanted to analyse the acute effects of physiological DHEA substitution on substrate metabolism.

Design: We studied nine females with adrenal insufficiency after 9 days of oral DHEA replacement ( $50 \mathrm{mg} /$ day) in a double-blind, placebo-controlled crossover study.

Methods: Whole body and regional substrate metabolism was assayed in the basal state and during a euglycemic hyperinsulinemic glucose clamp by means of isotope dilution techniques (glucose, phenylalanine, tyrosine), indirect calorimetry and in situ lipolysis (microdialysis technique).

Results: DHEA treatment normalized the levels of all androgens. Basal and insulin-stimulated total energy expenditure and rates of protein, lipid and glucose oxidation were unaffected by DHEA. Whole body turnover of glucose and protein were also unaffected by DHEA. Forearm breakdown of protein was reduced by insulin to the same extent after placebo and DHEA. Insulin sensitivity as expressed by the glucose infusion rate during the euglycemic clamp was similar after placebo and DHEA. Finally, the interstitial release of glycerol in adipose tissue was not significantly influenced by DHEA.

Conclusions: Short-term oral DHEA replacement in women with adrenal insufficiency was not associated with measurable changes in total or regional substrate metabolism.
\end{abstract}

European Journal of Endocrinology 152 77-85

\section{Introduction}

Dehydroepiandrosterone (DHEA) is mainly synthesized by the adrenal glands and is the most abundant circulating steroid hormone. In peripheral tissues, DHEA is converted to sex hormones, thereby contributing to the circulating levels of estradiol and testosterone, particularly in postmenopausal women (1). DHEA possibly also exerts an 'intracrine' action in local tissues, which may determine androgen status independently of the circulating sex hormone concentrations (1). However, the physiological significance of DHEA in vivo remains unclear. By introducing the term 'intracrinology' (1) it has been hypothesized that circulating DHEA following uptake in peripheral tissues is converted in situ to more potent androgens, which subsequently become inactivated at the cellular level. In this way, an androgenic or estrogenic action is mediated according to local tissue expression of steroidogenic enzymes and not reflected by the amount of circulating sex hormones (2). It is further speculated that total (endo- and 'intracrine') androgen production in women is more than two-thirds of that observed in men judged by the levels of conjugated metabolites of androgens and estrogens (1). Unlicensed use of DHEA is widespread in some countries, but the alleged beneficial effects and product content are uncertain $(3,4)$. Rodent models are of limited value since pronounced adrenal DHEA secretion is unique to higher primates (5). In female adrenal insufficiency, DHEA secretion is impaired and circulating androgen levels are severely reduced. DHEA substitution with $50 \mathrm{mg}(6-8)$ or less $(9,10)$ has been shown to normalize the circulating levels of DHEA and androgens. With this background, we have performed a shortterm, placebo-controlled crossover study to test whether the regulation of fuel metabolism in women depends on circulating androgen levels in the physiological range. We performed in-depth assessment of basal and insulin-stimulated substrate metabolism, including indirect calorimetry, isotopical determination of glucose and protein turnover, forearm 
exchange of metabolites and in situ lipolysis by means of microdialysis in adipose tissues.

\section{Subjects and methods}

\section{Study population}

The study population comprised nine females with adrenal failure (eight with Addison's disease and one monotrope ACTH failure) and a mean age of 42 years (range 22-54), with a mean duration of disease of 6.9 years (1-16 years). All participants were on stable hydrocortisone $(15-30 \mathrm{mg} /$ day) and fluorocortisone $(0-0.20 \mathrm{mg} /$ day $)$ treatment. One of two postmenopausal patients was treated with vaginal estradiol (vaginal capsules containing $25 \mu \mathrm{g}$ ). Three of seven naturally menstruating patients used combined oral contraceptives. Other concomitant medication included thyroid hormones (two patients), calcium and vitamin D (three patients), bisphosphonate (one patient) and hydroxycobalamin (one patient). None of the participants had previously received DHEA or androgens and none of them had diabetes. They were studied during the early follicular phase (day 5-10) of their regular cycle or in the corresponding phase of an oral contraceptive cycle induced by cortisol. The protocol was approved by the Århus County Ethical Scientific Committee (no. 1998/4375). All participants gave informed oral and written consent.

\section{Study protocol}

The patients were treated for 9 days with a daily morning dose of DHEA $(50 \mathrm{mg}$ ) or placebo in a double-blind, randomized, placebo-controlled crossover design. Each treatment period was separated by a wash-out period of at least 2 months. During the treatment period, participants continued normal daily living. At day 8, participants were admitted to the laboratory for clinical evaluation. During this period hydrocortisone substitution (Solucortef; Pharmacia, Stockholm, Sweden) was administered as a continuous infusion in a hand vein. The infusion rate was modified according to Hangaard et al. (11) (0800-1400 h, $0.026 \mathrm{mg} / \mathrm{kg}$ per h; $1400-0200 \mathrm{~h}, \quad 0.014 \mathrm{mg} / \mathrm{kg}$ per h; $\quad 0200-1400 \mathrm{~h}$, $0.026 \mathrm{mg} / \mathrm{kg}$ per h). Three standardized meals (total $2000 \mathrm{kcal}(15 \%$ protein, $50 \%$ cabohydrate and 35\% fat)) were served $(0830,1200$ and $1800 \mathrm{~h})$ and thereafter patients fasted. Inter-meal snacks and caloric beverages were avoided. Starting at $0800 \mathrm{~h}$ a 24-h hormonal profile was obtained and urine production was collected. Blood samples were drawn in a contralateral cubital vein every 20 min for growth hormone $(\mathrm{GH})$ measurements (previously published (12)) and every $60 \mathrm{~min}$ for blood glucose and other hormones. At $1500 \mathrm{~h}$ two microdialysis catheters were placed in abdominal and femoral subcutaneous adipose tissue respectively. On day 9 , fuel metabolism was estimated during fasting (basal period) and during meal simulation by means of insulin and amino acid stimulation (clamp period) (Fig. 1), and all data presented are from this study day. One catheter was placed retrogradely in a deep antecubital vein and one catheter was inserted retrogradely in a heated contralateral dorsal hand vein, allowing collection of venous blood draining the forearm muscle and oxygenated blood from digital capillary shunting respectively. Criteria for correct positioning were oxygen saturation below $70 \%$ and above $91 \%$ respectively. A third catheter was placed anterogradely in a cubital vein of the heated hand for infusions. The study was conducted and monitored according to the International Conference on Harmonisation - Good Clinical Practice (GCP) guidelines (The GCP Unit, Århus University Hospital). The study drug was produced according to Good Manufacturing Practise (GMP) in a licensed laboratory (Terapharm, Katwijk, The Netherlands). Raw materials fulfilled the requirements of the European Pharmacopea (edn 3). Final analyses document the tests corresponding to the requirements for capsules in the European Pharmacopea. That means uniformity of content, uniformity of mass and disintegration of capsules. According to the analysis certificate the results were: assay $101.5 \%(95-105 \%)$, mean weight variation $410.4 \pm 3.6 \mathrm{mg}(401-419 \mathrm{mg})$ and disintegration $3 \mathrm{~min}(<15 \mathrm{~min})$. Figures in parentheses indicate the requirements of the law.

\section{Tracers and clamp}

At $0800 \mathrm{~h}$ priming doses of $\left[3-{ }^{3} \mathrm{H}\right] \mathrm{glucose}(20 \mu \mathrm{Ci}$; New England Nuclear, Boston, MA, USA) and L- $\left[{ }^{15} \mathrm{~N}\right]$ phenylalanine $(0.7 \mathrm{mg} / \mathrm{kg}), \mathrm{L}-\left[{ }^{2} \mathrm{H}_{4}\right]$ tyrosine $(0.5 \mathrm{mg} /$ $\mathrm{kg})$ and $\mathrm{L}-\left[{ }^{15} \mathrm{~N}\right]$ tyrosine $(0.3 \mathrm{mg} / \mathrm{kg})$ (Cambridge Isotope Laboratories, Inc., Andover, MA, USA) were given to accomplish an early plateau. A continuous infusion of $\left[3-{ }^{3} \mathrm{H}\right]$ glucose $(20 \mu \mathrm{Ci} / \mathrm{h}), \quad \mathrm{L}-\left[{ }^{15} \mathrm{~N}\right]$ phenylalanine

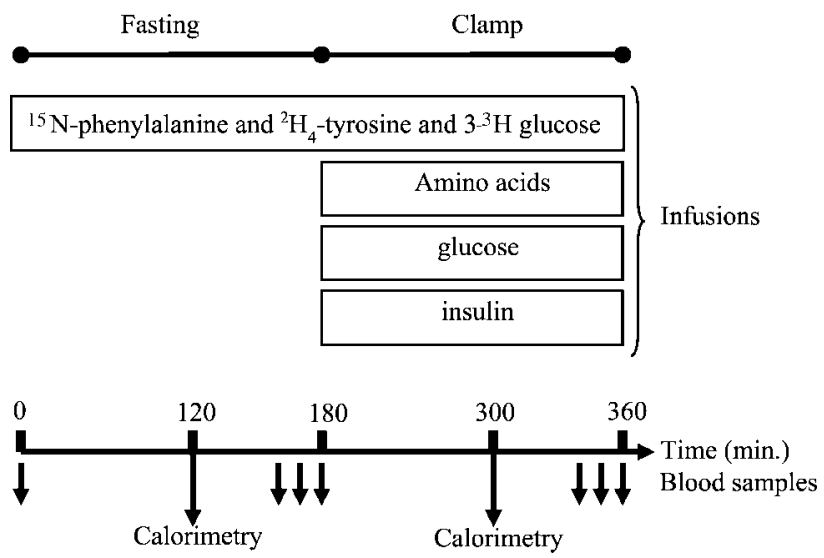

Figure 1 The figure depicts when determination of phenylalanine, tyrosine and glucose kinetics was performed (short arrows). The experiment consisted of a $180-$ min basal period followed by a 180-min hyperinsulinemic, euglycemic clamp. Blood samples were taken in triplicate after 150 and $330 \mathrm{~min}$ to ensure steady state. Indirect calorimetry was performed after 120 and $300 \mathrm{~min}$ (long arrows). 
$(0.7 \mathrm{mg} / \mathrm{kg}$ per $\mathrm{h})$ and $\mathrm{L}-\left[{ }^{2} \mathrm{H}_{4}\right]$ tyrosine $(0.5 \mathrm{mg} / \mathrm{kg}$ per $\mathrm{h})$ was started and maintained for $6 \mathrm{~h}$. Tracer solutions were prepared according to GMP guidelines by the hospital pharmacy (Århus University Hospital). After $3 \mathrm{~h}$ an intravenous infusion of insulin (Actrapid; Novo Nordisk, Copenhagen, Denmark) and amino acid (Glavamin; Fresenius Kabi AB, Uppsala, Sweden) was commenced. Glucose was infused at a variable rate to ensure euglycemia according to frequent measurement of plasma glucose concentrations.

\section{Microdialysis and calculations}

Microdialysis fibers (CMA 60 microdialysis catheter; CMA, Stockholm, Sweden) were placed in abdominal and femoral subcutaneous adipose tissue. Immediately after placement, fibers were perfused at a rate of $1 \mu \mathrm{l} / \mathrm{min}$ (CMA-107 perfusion pump; CMA, Stockholm). To the perfusion fluid (Ringer chloride, T1; CMA, Stockholm; $\mathrm{Na}^{+} 147 \mathrm{mmol} / \mathrm{l} ; \mathrm{K}^{+} 1.4 \mathrm{mmol} / \mathrm{l}$; $\mathrm{Ca}^{2+} 2.3 \mathrm{mmol} / \mathrm{l} ; \mathrm{Cl}^{-} 156 \mathrm{mmol} / \mathrm{l}, \mathrm{pH}$ 6; osmolality, $290 \mathrm{mosmol} / \mathrm{kg}$ ) was added a small amount of $\left[{ }^{3} \mathrm{H}\right]$ glycerol in order to measure the relative recovery by an internal reference method (13). Samples were collected every hour from 2100 to $1400 \mathrm{~h}$. An automated spectrophotometric kinetic enzymatic analyzer (CMA 600; CMA, Solna, Sweden) was used for duplicate measurements of glycerol, glucose, urea and lactate in the microdialysate. Changes in interstitial glycerol concentration were used as an index of lipolysis (14).

\section{Blood flow measurements}

The subcutaneous adipose tissue blood flow in the abdominal and femoral region in which dialysis was performed was measured by the local ${ }^{133} \mathrm{Xe}$ washout method (15). In short, $3.7 \mathrm{MBq}(0.1 \mathrm{ml}){ }^{133} \mathrm{Xe}$ was injected subcutaneously in the abdomen and femur. Disappearance of ${ }^{133} \mathrm{Xe}$ was continuously measured starting $30 \mathrm{~min}$ after injection using an $\mathrm{NaI}$ detector (Mediscint; Oakfield Instruments Ltd, Workingham, Berkshire, UK) as previously described (16). The tissue/blood partition coefficient was corrected for skinfold thickness as decribed by Bulow et al. (17). Forearm blood flow was determined by means of venous occlusion plethysmography.

\section{Indirect calorimetry}

Indirect calorimetry (Deltatrac Metabolic Monitor; Datex, Helsinki, Finland) was performed for $30 \mathrm{~min}$. The initial 5 min were used for acclimatization, and calculations of respiratory quotient and resting energy expenditure (REE) were based on mean values of 25 measurements of 1 min each. Likewise, rates of protein lipid and glucose oxidation were estimated corrected for urinary excretion of urea (18). Net non-oxidative glucose disposal was calculated by subtraction of glucose oxidation from the isotopically assayed total glucose disposal.

\section{Protein and glucose kinetics}

Whole body phenylalanine kinetics were estimated from the equations of Thompson et al. (19). Regional phenylalanine kinetics were estimated as previously described (20). Phenylalanine flux $\left(Q_{p}\right)$ and tyrosine flux $\left(Q_{t}\right)$ were calculated as follows: $Q_{\text {flux }}=\mathrm{i}\left[\left(\mathrm{E}_{\mathrm{i}} / \mathrm{E}_{\mathrm{p}}\right)-\right.$ $1]$ in which $\mathrm{i}$ is the rate of tracer infusion $(\mu \mathrm{mol} / \mathrm{kg}$ per min), and $E_{i}$ and $E_{p}$ are enrichment of the tracer infused and plasma enrichment of the tracer at isotopic plateau respectively.

The rate of phenylalanine conversion to tyrosine $\left(\mathrm{I}_{\mathrm{pt}}\right)$ was calculated as follows: $\mathrm{I}_{\mathrm{pt}}=\mathrm{Q}_{\mathrm{t}} \times$ $\left(\left[{ }^{15} \mathrm{~N}\right] \mathrm{Tyr}_{\mathrm{ei}} /\left[{ }^{15} \mathrm{~N}\right] \mathrm{Phe}_{\mathrm{ei}}\right) \times\left(\mathrm{Q}_{\mathrm{p}} /\left(\mathrm{I}_{\mathrm{p}}+\mathrm{Q}_{\mathrm{p}}\right)\right)$ where $\left[{ }^{15} \mathrm{~N}\right]$ $\mathrm{Tyr}_{\mathrm{ei}}$ and $\left[{ }^{15} \mathrm{~N}\right] \mathrm{Phe}_{\mathrm{ei}}$ are the isotopic enrichments of the respective tracers in plasma and $\mathrm{I}_{\mathrm{p}}$ is the infusion rate of $\left[{ }^{15} \mathrm{~N}\right]$ phenylalanine $(\mu \mathrm{mol} / \mathrm{kg}$ per $\mathrm{h})$. Protein synthesis was calculated by subtracting $\mathrm{I}_{\mathrm{pt}}$ from $Q_{\mathrm{p}}$, since phenylalanine is irreversibly lost either by conversion into tyrosine or by incorporation into protein.

In the forearm study, phenylalanine balance (PheBal) was calculated as follows: $\mathrm{PheBal}=\left(\mathrm{Phe}_{\mathrm{A}}-\mathrm{Phe}_{\mathrm{V}}\right) \times \mathrm{F}$ in which $\mathrm{Phe}_{\mathrm{A}}$ and $\mathrm{Phe}_{\mathrm{V}}$ are phenylalanine concentrations in arteries and veins and $\mathrm{F}$ is bloodflow.

Regional protein breakdown represented by phenylalanine rate of appearance (RaPhe) was calculated as follows (21) $\mathrm{RaPhe}=\mathrm{Phe}_{\mathrm{A}}\left[\left(\mathrm{Phe}_{\mathrm{EA}} / \mathrm{Phe}_{\mathrm{EV}}\right)-1\right] \times \mathrm{F}$ in which Phe $_{\mathrm{EA}}$ and $\mathrm{Phe}_{\mathrm{EV}}$ represent phenylalanine isotopic enrichment in arteries and veins.

Local rate of disappearance $(R \mathrm{~d})$ was calculated as RdPhe $=$ PheBal + RaPhe .

The specific activity of tritiated glucose was measured as described (22). Rates of appearance (Ra) and $R d$ of glucose were calculated using Steele's equation for nonsteady state, and a pool fraction of 0.65 was used. Endogenous glucose production during the clamp was calculated by subtracting the rate of glucose infusion ( $M$ value) from glucose $\mathrm{Ra}$, as determined isotopically. $\mathrm{L}-\left[{ }^{15} \mathrm{~N}\right]$ phenylalanine, L- $\left[{ }^{2} \mathrm{H}_{4}\right]$ tyrosine and L- $\left[{ }^{15} \mathrm{~N}\right]$ tyrosine were measured as their $t$-butyldimethylsilyl ether derivatives under electron ionization conditions (20). Plasma concentrations of amino acids were determined by an HPLC system (Bio-Tek Kontron, Series 525 and 465, fluorescence detector SFM25, Kontron Instruments, Milan, Italy) with precolumn O-phthalaldehyde derivatization. In addition, concentrations of phenylalanine and tyrosine were measured by mass spectrometry using $\mathrm{L}-\left[{ }^{2} \mathrm{H}_{8}\right]$ phenylalanine and $\mathrm{L}-\left[{ }^{13} \mathrm{C}_{6}\right.$ ]tyrosine as internal standards respectively (20). Plasma glucose levels were measured in duplicate immediately after sampling on a glucose analyzer (Beckman Instruments, Palo Alto, CA, USA).

\section{Hormone assays}

Plasma glucagon and serum C-peptide were measured by radioimmunaassays (Immunoclear, Stillwater, MN, USA). Serum insulin-like growth factor (IGF)-I was measured by an in-house non-competitive time-resolved 
immunofluorometric assay (23). Insulin was determined by a commercial enzyme-linked immunosorbent assay (DAKO, Glostrup, Denmark). Blood levels of alanine, glycerol, 3-hydroxybutyrate and lactate were assayed with an automated fluorometric method (24). Urea excretion in urine was determined by an indophenol method and serum urea by a commercial kit (COBAS INTEGRA; Roche, Hvidovre, Denmark). Cortisol was measured by an automated chemiluminescence system (Chiron Diagnostics, Fernwald, Germany). Free fatty acids (FFA) were determined by a colorimetric method employing a commercial kit (Wako Chemicals, Neuss, Germany). Total and free hormone concentrations of thyroxine $\left(\mathrm{T}_{4}\right)$ and tri-iodothyronine $\left(\mathrm{T}_{3}\right)$ were measured in serum as previously described (25), while thyrotropin (TSH) was measured in a solid-phase, two-site chemiluminescent enzyme immunometric assay (IMMULITE; DPC, Los Angeles, CA, USA). Androgens, estrogens and sex hormone-binding globulin (SHBG) were analysed as described (26). Mean and normal range (in parenthesis), and inter- and intra-assay coefficients of variation respectively were as follows: SHBG: 83 (41-170) $\mathrm{nmol} / \mathrm{l}, 7.5 \%$, 5.2\%; testosterone: 1.00 (0.55-1.80) $\mathrm{nmol} / \mathrm{l}, 13.8 \%$, 8.2\%; free testosterone: 0.014 (0.006$0.034) \mathrm{nmol} / \mathrm{l}, 6.4 \%, 4.7 \%$; dihydrotestosterone (DHT): $0.50(0.25-1.20) \mathrm{nmol} / \mathrm{l}, 11.0 \%, 9.1 \%$; $\alpha$-4-androstendione: 4.7 (2.4-8.9) nmol/l, 11.4\%, 9.4\%; DHEA: 5.5 (1.4-12.5) nmol/l, $11.5 \%, 8.5 \%$; DHES sulphate (DHEAS): $4500(1200-9500) \mathrm{nmol} / \mathrm{l}, 11.5 \%, 8.5 \%$; 17ß-oestradiol: $120(<40-400) \mathrm{pmol} / \mathrm{l}, 10.5 \%, 7.4 \%$; estrone: $140(70-270) \mathrm{pmol} / \mathrm{l}, 9.6 \%, 7.0 \%$.

\section{Statistical analysis}

As appropriate for parametric and non-parametric data, measurements are expressed as means \pm s.E.M. or median and range, and comparisons were done with Student's paired t-test or Wilcoxon signed rank test. We were not able to perform a power analysis prior to performing the study because of the lack of data in the literature regarding the impact of DHEA treatment on the measured parameters. We therefore chose $n=9$, since in previous studies with the same methodology we have found a clinically significant impact of short-term interventions. Significance levels less than $5 \%$ were considered significant.

\section{Results}

\section{Sex hormones}

Baseline androgen values (nmol/l) increased to physiological levels following DHEA treatment (placebo vs DHEA (median, range)); DHEA: 1.55 (0.39-3.99) vs 5.16 (2.2-11.42), $(P=0.011)$; DHEAS: 99 (99$440)$ vs 2800 (1100-8300), $(P=0.008)$; androstendione: $1.39(0.37-3.07)$ vs $2.52(0.19-4.18)$,
$(P=0.021) ; \quad$ DHT: $0.245 \quad(0.175-0.385)$ vs 0.46 (0.19-0.90), $(P=0.015)$; testosterone: 0.46 (0.26$0.78)$ vs $0.82(0.38-1.32),(P=0.011)$; free testosterone: 0.0075 (0.0025-0.009) vs 0.01 (0.01-0.02), $(P=0.018)$; DHEAS/testosterone ratio $(341 \pm 65$ vs 4379 \pm 671 , $(P<0.001))$ (Fig. 2). Estradiol (nmol/l) did not change significantly $(84.5(39-420)$ vs 160 (39-320), $(P=0.612))$.

\section{Microdialysis}

Interstitial concentrations in subcutaneous fat of glycerol are shown in Fig. 3. No effect of DHEA treatment was seen (placebo vs DHEA, glycerol area under the curve (AUC) ( $\mu \mathrm{mol} / \mathrm{l})$, abdominal: $351 \pm 44$ vs $314 \pm 31$, $(P=0.456)$, femoral: $300 \pm 50$ vs $302 \pm 34$, $(P=0.959))$. Nor did DHEA induce changes in other interstitial metabolites (lactate and glucose, data not shown). Adipose tissue blood flow did not differ between the two treatments (data not shown).

\section{Glucose, circulating hormones and metabolites}

Twenty-four hour profiles of glucose, insulin, cortisol and IGF-binding protein (IGFBP)-1 were very similar under the two conditions (glucoseAUC: $5.1 \pm 0.1$ vs $5.1 \pm$ $0.1 \mathrm{mmol} / \mathrm{l}$ per h, $(P=0.922)$; insulinAUC: $120 \pm 20 \mathrm{vs}$ $126 \pm 18 \mathrm{pmol} / \mathrm{l}$ per $\mathrm{h}, \quad(P=0.357) ; \quad$ cortisolAUC $270 \pm 50$ vs $278 \pm 53 \quad(\mathrm{mmol} / \mathrm{l}$ per h), $\quad(P=0.630)$; IGFBP-1AUC $1.67 \pm 0.17$ vs $1.88 \pm 0.32$ ( $\mu \mathrm{g} / \mathrm{l}$ per $\mathrm{h})$, $(P=0.372))$ (Fig. 4). During the experiment, day 9 levels of circulating hormones were similar between treatments both during fasting and during insulin and amino acid stimulation (clamp) (Table 1). Arterial concentrations of alanine, lactate, glycerol, 3-hydroxybutyrate and FFAs are shown in Table 2. DHEA treatment did not modulate these circulating metabolites in either arterial or venous blood, or as regards the arterial to venous difference (data not shown).

\section{Whole body protein metabolism}

Plasma concentrations of amino acids (Table 3) and serum urea were similar in both conditions (placebo vs DHEA, urea (mmol/l): $4.89 \pm 0.26$ vs $4.80 \pm 0.26$, $(P=0.625))$. Twenty-four hour urinary urea excretion rate (UER) and UER during fasting (basal) and during insulin and amino acid stimulation (clamp) were unaffected by DHEA treatment (UER $24 \mathrm{~h}: 14.3 \pm 1.0$ vs $14.2 \pm 1.1 \mathrm{mmol} / \mathrm{h},(P=0.963)$; UERbasal: $16.4 \pm 5.3$ vs $\quad 16.1 \pm 3.8 \mathrm{mmol} / \mathrm{h}, \quad(P=0.961)$; $\quad$ UERclamp: $18.8 \pm 1.8$ vs $15.2 \pm 2.0 \mathrm{mmol} / \mathrm{h},(P=0.224))$. Phenylalanine and tyrosine fluxes remained unaffected by DHEA treatment in both the basal and clamp period (Table 3). Neither phenylalanine conversion to tyrosine, representing amino acid breakdown, nor protein 

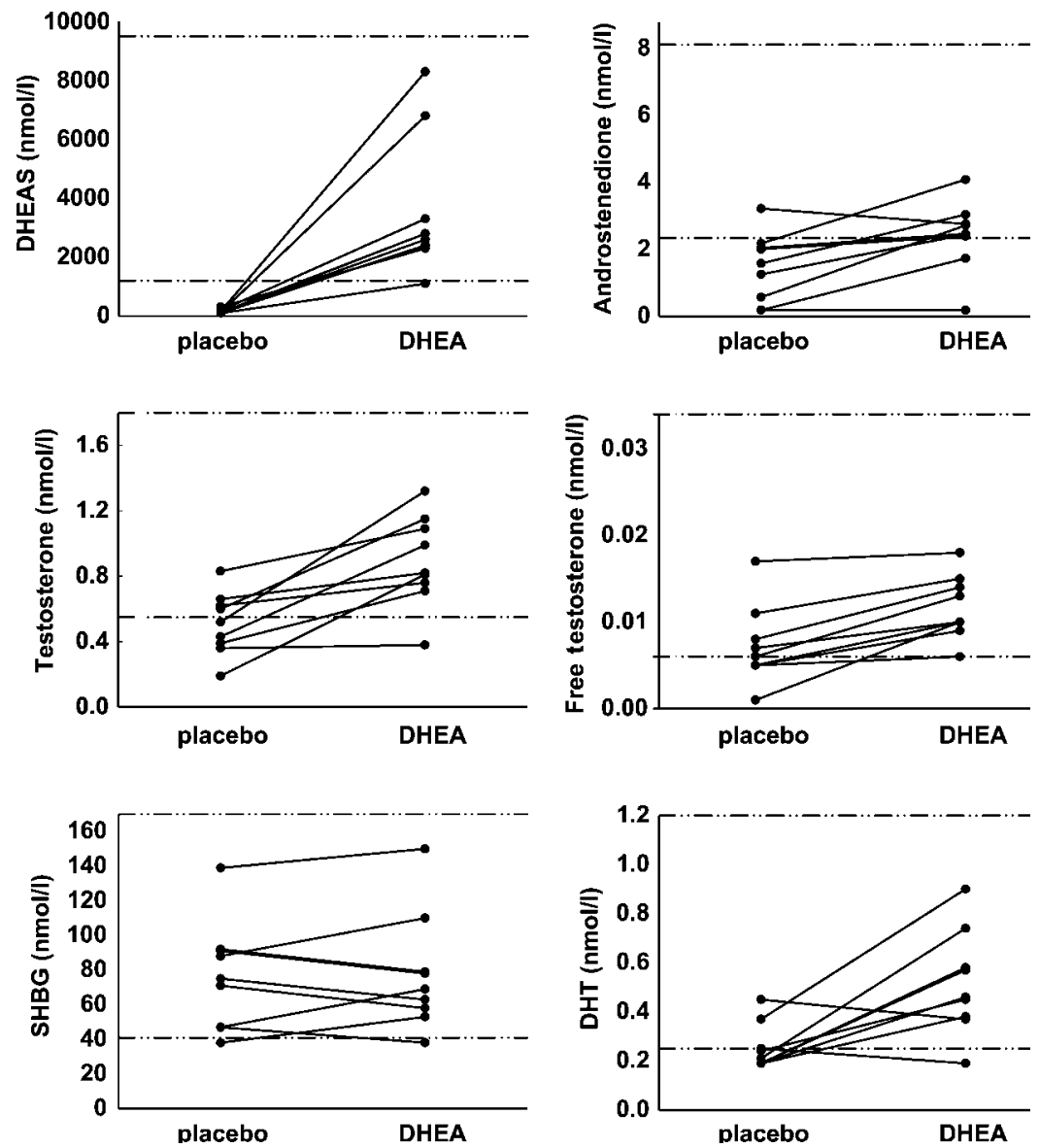

Figure 2 Circulating androgens before and during DHEA treatment. Individual values are depicted, with a line connecting baseline data and during DHEA treatment. Upper and lower limits of normal reference values for women are depicted by the broken lines.

synthesis (phenylalanine disposal not accounted for by phenylalanine conversion to tyrosine) were significantly influenced by DHEA treatment.

\section{Forearm protein metabolism}

Forearm blood flow decreased under DHEA treatment in the basal period, but this was not significant during insulin stimulation. Forearm muscle exhibited an equal net release of phenylalanine during the basal period in both treatment conditions (Table 3). Insulin and amino acid stimulation converted this into a positive balance with no significant influence of DHEA treatment. Muscle protein breakdown, represented by phenylalanine rate of appearance, was equal in both the basal and clamp period. Incorporation of phenylalanine into muscle, represented by the phenylalanine rate of disappearance, was also not affected by active treatment.

\section{Indirect calorimetry and glucose turnover}

REE was not altered by DHEA treatment (placebo vs DHEA; REEbasal: $1263 \pm 54$ vs $1282 \pm 48 \mathrm{kcal} / 24 \mathrm{~h}$, $(P=0.602)$; REEclamp: $1466 \pm 59$ vs $1422 \pm 47 \mathrm{kcal} /$
$24 \mathrm{~h},(P=0.099))$, and fuel oxidation was similarly distributed between protein (ProtOx), glucose (GlucOx) and lipid (LipOx) (placebo vs DHEA; ProtOxbasal: $407 \pm 130$ vs $399 \pm 95 \mathrm{kcal} / 24 \mathrm{~h},(P=0.96)$; ProtOxclamp: $465 \pm 43$ vs $376 \pm 50 \mathrm{kcal} / 24 \mathrm{~h}(P=0.22)$; GlucOxbasal: $454 \pm 90$ vs $418 \pm 53 \mathrm{kcal} / 24 \mathrm{~h},(P=0.70)$; GlucOxclamp: $640 \pm 50$ vs $763 \pm 76 \mathrm{kcal} / 24 \mathrm{~h}, \quad(P=$ 0.28); LipOxbasal: $403 \pm 94$ vs $466 \pm 85 \mathrm{kcal} / 24 \mathrm{~h}$, $(P=0.67)$; LipOxclamp: $360 \pm 83$ vs $283 \pm 85 \mathrm{kcal} /$ $24 \mathrm{~h}, \quad(P=0.51))$. Endogenous glucose production (EGP), glucose rate of disappearance (GlcRd) and nonoxidative glucose disposal (Nonox disp) were also similar under the two conditions (placebo vs DHEA; EGPbasal: $0.1051 \pm 0.0071 \mathrm{vs} 0.1042 \pm 0.0119 \mathrm{mg} / \mathrm{kg}$ per $\min ,(P=0.746)$; EGPclamp: $-1.9221 \pm 0.2083 \mathrm{vs}$ $-1.988 \pm 0.2300 \mathrm{mg} / \mathrm{kg}$ per $\min ,(P=0.952)$; GlcRdbasal: $0.1070 \pm 0.0082$ vs $0.1053 \pm 0.0115 \mathrm{mg} / \mathrm{kg}$ per min, $(P=0.620)$; GlcRdclamp: $0.1769 \pm 0.0130$ vs $0.1727 \pm 0.0131 \mathrm{mg} / \mathrm{kg}$ per $\min ,(P=0.147)$; Nonox dispbasal: $0.55 \pm 0.48$ vs $0.76 \pm 0.31 \mathrm{mg} / \mathrm{kg}$ per min, $(P=0.671)$; Nonox dispclamp: $1.25 \pm 0.20$ vs $1.01 \pm$ $0.31 \mathrm{mg} / \mathrm{kg}$ per min, $(P=0.647))$. DHEA treatment did not alter insulin sensitivity ( $M$ value) (placebo vs DHEA: $2.17 \pm 0.17$ vs $2.15 \pm 0.23 \mathrm{mg} / \mathrm{kg}$ per $\mathrm{min}$, $(P=0.942))$. 


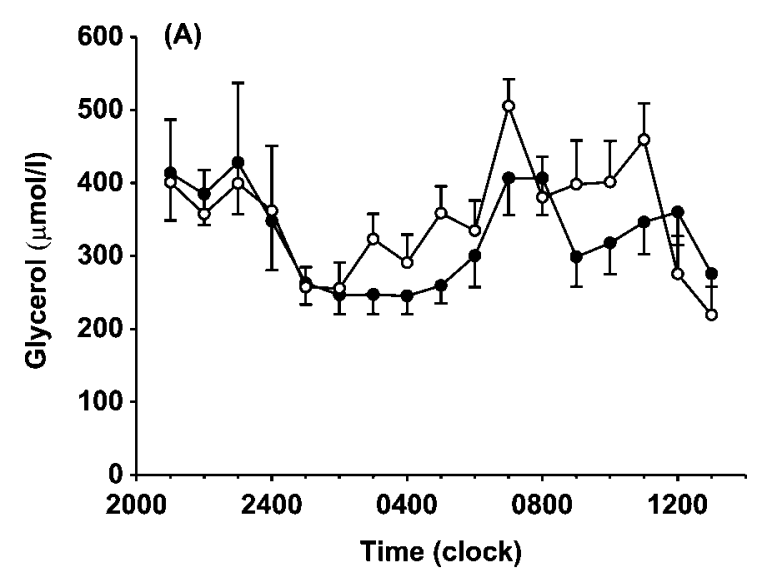

(B)

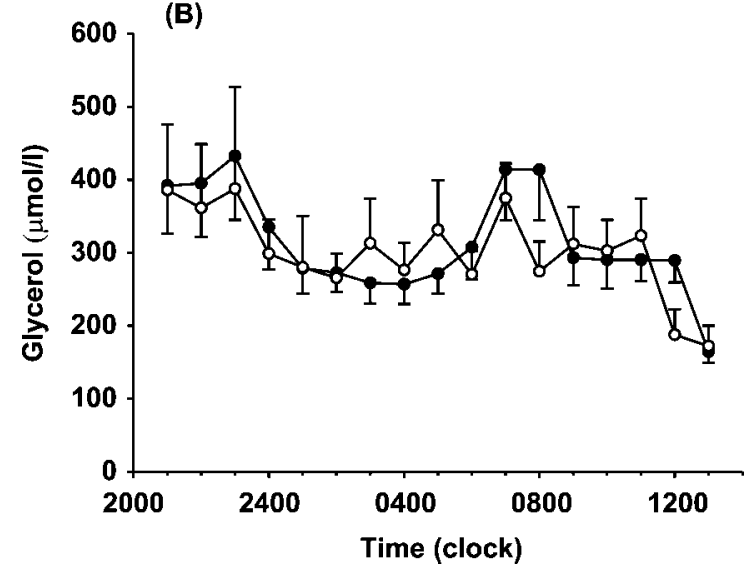

Figure 3 Effects of DHEA $(\bullet)$ and placebo $(0)$ treatment on 17-h interstitial glycerol dynamics, as an index of subcutaneous fat lipolysis, measured with an (A) abdominal and (B) femoral microdialysis catheter. The values presented are means \pm S.E.M.

\section{Discussion}

In the present study we have evaluated the short-term effects of physiological DHEA replacement in women with adrenal failure on substrate metabolism in the basal state as well as during infusion of insulin, glucose and amino acids. We found no significant effects of DHEA treatment. During both study days an identical cortisol substitution was given as an infusion to avoid a confounding effect of differential absorption from the gut of orally given cortisol tablets. These data suggested that acute alterations in adrenal androgens play only a limited role in the physiological regulation of substrate metabolism in women. Testosterone is believed to be the primary anabolic androgen in muscle (27) acting both through direct effects on a nuclear androgen receptor, and through indirect effects on transcription factors and mediators that modulate gene expression (28). Upon short-term physiological androgen substitution with DHEA in this study, we induced a twofold increase in DHT and testosterone but observed neither increased muscle protein synthesis
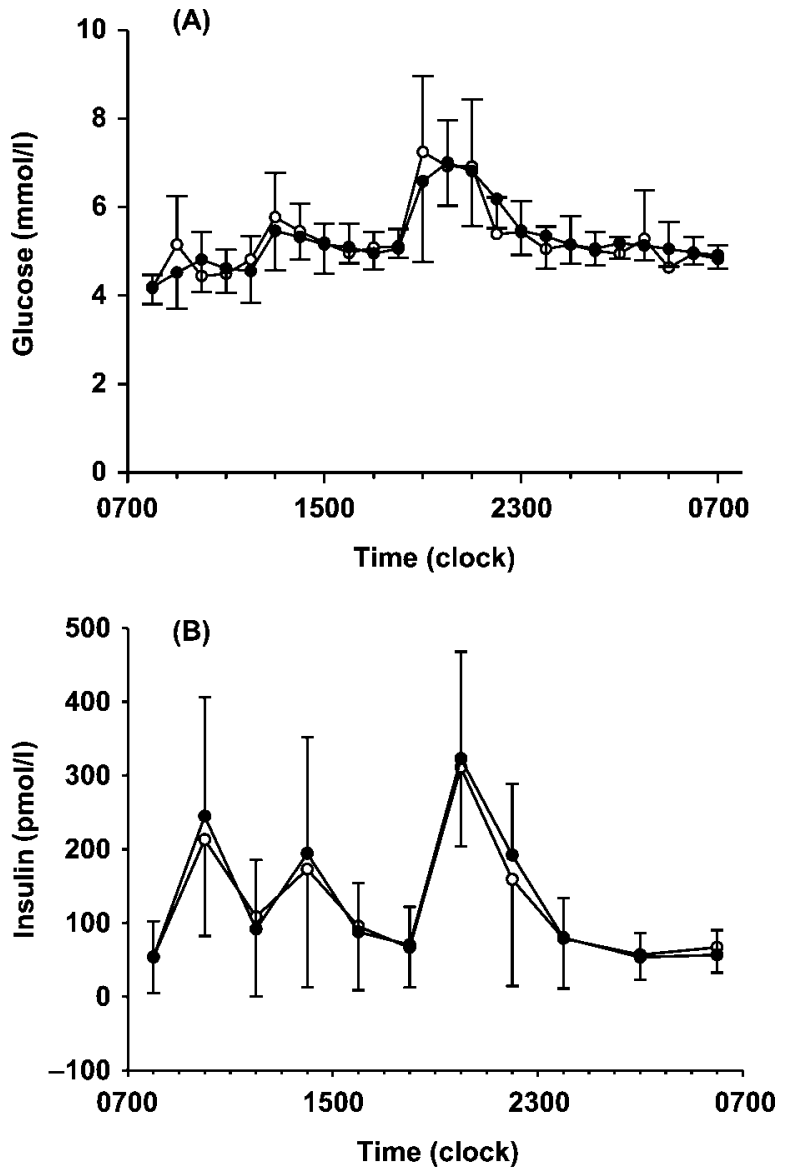

(C)

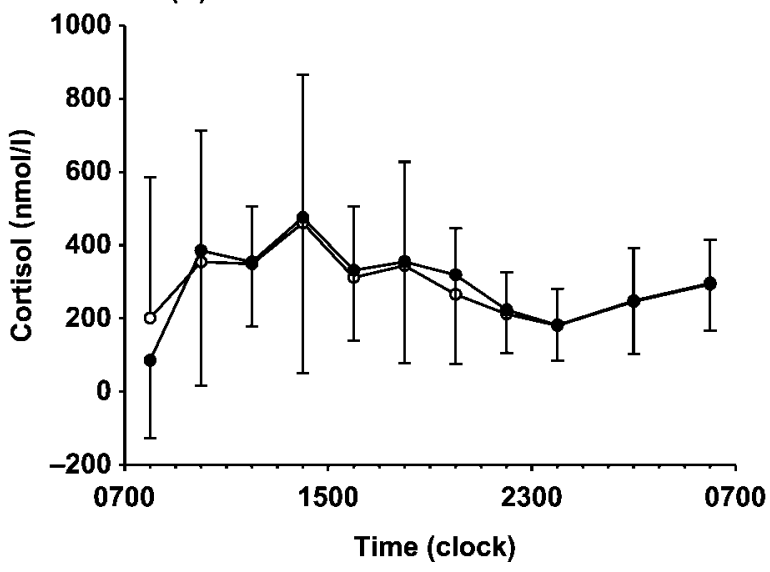

Figure 4 Effects of DHEA $(\bullet)$ and placebo $(\circ)$ treatment in female adrenal failure on 24-h serum profile of (A) glucose, $(B)$ insulin and $(C)$ cortisol. The values presented are means \pm S.E.M.

nor reduced amino acid release, and we found no evidence of stimulated subcutaneous fat mobilization estimated by in situ glycerol release. DHEA substitution in female adrenal failure during 3 (29) and 4 months (6) did not influence body composition, but after 6 and 12 months an increase in lean body mass was detected (9), though this was only seen in the open labeled part of 
Table 1 Effects of DHEA and placebo treatment, in female adrenal failure, on circulating hormones, during fasting condition and during insulin and amino acid stimulation.

\begin{tabular}{|c|c|c|c|c|c|c|}
\hline & \multicolumn{3}{|c|}{ Fasting } & \multicolumn{3}{|c|}{ Stimulated } \\
\hline & Placebo & DHEA & $P$ & Placebo & DHEA & $P$ \\
\hline Cortisol (nmol/l) & $286 \pm 39$ & $284 \pm 44$ & 0.807 & $291 \pm 44$ & $302 \pm 42$ & 0.498 \\
\hline Insulin (pmol//) & $51.7 \pm 11.2$ & $47.4 \pm 7.2$ & 0.414 & $315.7 \pm 50.8$ & $286.0 \pm 52.9$ & 0.916 \\
\hline IGF-I ( $\mu \mathrm{g} / \mathrm{l})$ & $172.1 \pm 8.3$ & $176.3 \pm 7.3$ & 0.661 & $172.7 \pm 9.3$ & $170.9 \pm 8.7$ & 0.426 \\
\hline IGFBP-1 ( $\mu \mathrm{g} / \mathrm{l})$ & $3.61 \pm 0.54$ & $4.31 \pm 0.67$ & 0.341 & $2.65 \pm 0.34$ & $3.04 \pm 0.47$ & 0.321 \\
\hline TSH $(\mu \mathrm{mol} / \mathrm{ml})$ & $1.67 \pm 0.30$ & $1.44 \pm 0.29$ & 0.179 & & & \\
\hline $\mathrm{T}_{3}(\mathrm{nmol} / \mathrm{l})$ & $1.19 \pm 0.07$ & $1.18 \pm 0.05$ & 0.786 & & & \\
\hline $\mathrm{T}_{4}(\mathrm{nmol} / \mathrm{l})$ & $79.7 \pm 4.8$ & $78.1 \pm 3.3$ & 0.564 & & & \\
\hline
\end{tabular}

Table 2 Effects of placebo and DHEA treatment on arterial metabolite concentrations, during fasting and during insulin and amino acid stimulation.

\begin{tabular}{|c|c|c|c|c|c|c|}
\hline \multirow[b]{2}{*}{ Concentrations $(\mu \mathrm{mol} / \mathrm{l})$} & \multicolumn{3}{|c|}{ Fasting } & \multicolumn{3}{|c|}{ Stimulated } \\
\hline & Placebo & DHEA & $P$ & Placebo & DHEA & $P$ \\
\hline Alanine & $246 \pm 13$ & $263 \pm 19$ & 0.537 & $504 \pm 20$ & $500 \pm 22$ & 0.850 \\
\hline Lactate & $591 \pm 51$ & $628 \pm 77$ & 0.575 & $605 \pm 23$ & $647 \pm 24$ & 0.284 \\
\hline Glycerol & $64.2 \pm 5.9$ & $65.6 \pm 9.2$ & 0.877 & $20.2 \pm 2.3$ & $25.3 \pm 3.5$ & 0.233 \\
\hline 3-Hydroxybutyrate & $142.4 \pm 37.2$ & $170.2 \pm 52.9$ & 0.326 & $2.4 \pm 0.5$ & $2.6 \pm 0.8$ & 0.531 \\
\hline FFA & $0.575 \pm 0.08$ & $0.588 \pm 0.088$ & 0.818 & $0.071 \pm 0.018$ & $0.075 \pm 0.025$ & 0.611 \\
\hline
\end{tabular}

Table 3 Effects of DHEA and placebo treatment in female adrenal failure on phenylalanine and tyrosine fluxes in both whole body and forearm.

\begin{tabular}{|c|c|c|c|c|c|c|}
\hline & \multicolumn{3}{|c|}{ Fasting } & \multicolumn{3}{|c|}{ Stimulated } \\
\hline & Placebo & DHEA & $P$ & Placebo & DHEA & $P$ \\
\hline \multicolumn{7}{|l|}{ Whole body } \\
\hline $\begin{array}{l}\text { Total Qphe } \\
(\mu \mathrm{mol} / \mathrm{kg} \text { per } \mathrm{h})\end{array}$ & $37.16 \pm 2.59$ & $38.85 \pm 1.99$ & 0.308 & $62.25 \pm 2.04$ & $64.21 \pm 2.92$ & 0.981 \\
\hline $\begin{array}{l}\text { Endogen Qphe } \\
\quad(\mu \mathrm{mol} / \mathrm{kg} \text { per } \mathrm{h})\end{array}$ & & & & $24.28 \pm 2.05$ & $26.25 \pm 2.92$ & 0.981 \\
\hline $\begin{array}{l}\text { Total Qtyr } \\
\quad(\mu \mathrm{mol} / \mathrm{kg} \text { per } \mathrm{h})\end{array}$ & $32.83 \pm 1.75$ & $32.68 \pm 0.92$ & 0.914 & $45.00 \pm 2.00$ & $46.09 \pm 1.27$ & 0.878 \\
\hline $\begin{array}{l}\text { Endogen Qtyr } \\
\quad(\mu \mathrm{mol} / \mathrm{kg} \text { per h })\end{array}$ & & & & $31.70 \pm 2.00$ & $32.79 \pm 1.27$ & 0.878 \\
\hline $\begin{array}{l}\text { Qpt } \\
\qquad(\mu \mathrm{mol} / \mathrm{kg} \text { per } \mathrm{h})\end{array}$ & $4.28 \pm 0.18$ & $4.00 \pm 0.22$ & 0.394 & $8.93 \pm 0.73$ & $7.47 \pm 0.82$ & 0.281 \\
\hline $\begin{array}{l}\text { Protein synthesis } \\
(\mu \mathrm{mol} / \mathrm{kg} \text { per } \mathrm{h})\end{array}$ & $32.88 \pm 2.57$ & $34.85 \pm 2.07$ & 0.220 & $53.32 \pm 2.44$ & $56.74 \pm 3.27$ & 0.678 \\
\hline \multicolumn{7}{|l|}{ Forearm } \\
\hline $\begin{array}{l}\text { BalPhe } \\
\text { (nmol/100 ml per min) }\end{array}$ & $-1.19 \pm 0.66$ & $-1.40 \pm 0.42$ & 0.794 & $0.31 \pm 1.75$ & $1.39 \pm 0.67$ & 0.737 \\
\hline $\begin{array}{l}\text { RaPhe } \\
\text { (nmol/100 ml per min) }\end{array}$ & $1.62 \pm 0.95$ & $2.51 \pm 1.31$ & 0.287 & $2.56 \pm 1.08$ & $2.78 \pm 0.88$ & 0.683 \\
\hline $\begin{array}{l}\text { RdPhe } \\
\text { (nmol/100 ml per min) }\end{array}$ & $0.43 \pm 0.61$ & $1.11 \pm 1.14$ & 0.354 & $2.87 \pm 2.23$ & $4.17 \pm 0.71$ & 0.578 \\
\hline $\begin{array}{l}\text { Flow } \\
\qquad(\mathrm{ml} / 100 \text { per } \mathrm{ml} \text { per } \mathrm{min})\end{array}$ & $2.59 \pm 0.51$ & $1.84 \pm 0.21$ & 0.005 & $2.23 \pm 0.38$ & $1.93 \pm 0.22$ & 0.384 \\
\hline
\end{tabular}

the trial. It therefore seems doubtful that physiological DHEA supplementation produces clinically relevant anabolic effects in women. Testosterone administration in female to male transsexuals increases thigh muscle area and reduces subcutaneous fat deposition (30), diminishes fat cell size and increases basal lipolysis estimated by in vitro glycerol release (31). In men, 5 days of testosterone or oxandrolone treatment $(32,33)$ but not androstendione (34) increases muscle protein synthesis. In hypoandrogenic men, body fat is increased (35) and, during long-term androgen replacement, muscle protein synthesis (36) and muscle mass increase concomitantly with a reduction in body fat (35). 
In females, reciprocal actions of DHEAS and testosterone on insulin have been proposed, with testosterone showing a positive correlation to stimulated insulin levels and negative to indices of insulin receptor binding, and DHEAS showing the opposite correlations (37). Comparing classical with non classical 21-hydroxylase deficiency (38) and congenital adrenal hyperplasia with polycystic ovary syndrome (39), the observed difference in insulin sensitivity has been explained by the DHEAS to testosterone ratio. Amelioration of insulin resistance in diabetes with DHEA in one female patient has been reported (40). In the present study, the DHEAS to testosterone ratio was over tenfold increased within the same person, without subsequent changes in glucose turnover and insulin sensitivity, indicating that it is unlikely that physiological replacement with DHEA influences glucose metabolism and insulin sensitivity. Our examination of carbohydrate metabolism and insulin sensitivity corroborates previous more longterm studies. DHEA treatment of women with adrenal insufficiency for 3 (29), 4 (6) and 12 months (9) did not affect fasting insulin and glucose levels. DHEA treatment (50-200 mg) for 3 months in same model was not followed by alterations in insulin sensitivity estimated by clamp (29) and treatment for 12 weeks in a gendermixed population did not affect insulin sensitivity estimated by homeostasis model assessment (7). So far no receptor for DHEA has been localized. In a recent paper (41), an endothelial plasma membrane receptor (41) activating G-proteins and endothelial nitric oxide synthase has been suggested. This could be the background for the observed decrease in forearm blood flow during DHEA treatment. Further investigation is needed to specify the physiological role of DHEA on the cardiovascular system.

In spite of the corrected circulating androgen status in our study population we did not detect any physiological effects by the applied methodologies. The subjects were studied after only short-term treatment in order to detect direct effects on substrate metabolism prior to possible changes in body composition and physical fitness. Indeed, 5 days of testosterone treatment has previously been shown to stimulate protein synthesis in men $(32,33)$. It remains possible, however, that more prolonged study would have translated into significant effects. Nevertheless, previous studies of longer duration have been unable to detect effects on glucose metabolism and insulin sensitivity, as mentioned above. The achieved androgen levels obtained were well below male levels and only in the lower part of normal female levels. It therefore remains possible that administration of DHEA in a higher dose or testosterone would have induced significant metabolic effects. Our sample size and design has previously been shown to be sufficient to detect significant changes following physiological exposure to $\mathrm{GH}$ and cortisol but it remains possible that a larger study population could have revealed subtle but significant effects of DHEA in our patients. Finally, the hydrocortisone substitution in this patient group only poorly imitates normal physiology, which may have interfered with the co-administration of DHEA.

In summary, we did not find any significant acute effects of exogenous DHEA on basal as well as stimulated substrate metabolism in women with adrenal insufficiency. We hypothesize that adrenal androgens play a limited role in the acute regulation of fuel metabolism.

\section{Acknowledgements}

J J C is supported by a $\mathrm{PhD}$ research fellowship by the University of Århus. Elsebeth Hornemann, Hanne Pedersen and Lone Svendsen are thanked for expert technical help. The study was supported by a grant from the Danish Health Research Council, grant number 9600822 (Århus University-Novo Nordisk Center for Research in Growth and Regeneration). The microdialysis catheters and other utensils were generously supplied by Roche Diagnostics.

\section{References}

1 Labrie F, Luu-The V, Labrie C, Belanger A, Simard J, Lin SX \& Pelletier G. Endocrine and intracrine sources of androgens in women: inhibition of breast cancer and other roles of androgens and their precursor dehydroepiandrosterone. Endocrine Reviews $200324152-182$.

2 Labrie F, Belanger A, Cusan L \& Candas B. Physiological changes in dehydroepiandrosterone are not reflected by serum levels of active androgens and estrogens but of their metabolites: intracrinology. Journal of Clinical Endocrinology and Metabolism $1997 \mathbf{8 2}$ 2403-2409.

3 Parasrampuria J, Schwartz K \& Petesch R. Quality control of dehydroepiandrosterone dietary supplement products. Journal of the American Medical Association 19982801565.

4 Thompson RD, Carlson M, Thompson RD \& Carlson M. Liquid chromatographic determination of dehydroepiandrosterone (DHEA) in dietary supplement products. Journal of AOAC International $2000 \mathbf{8 3} 847-857$.

5 Belanger B, Belanger A, Labrie F, Dupont A, Cusan L \& Monfette G. Comparison of residual $\mathrm{C}-19$ steroids in plasma and prostatic tissue of human, rat and guinea pig after castration: unique importance of extratesticular androgens in men. Journal of Steroid Biochemistry 198932 695-698.

6 Callies F, Fassnacht M, van Vlijmen JC, Koehler I, Huebler D, Seibel MJ, Arlt W \& Allolio B. Dehydroepiandrosterone replacement in women with adrenal insufficiency: effects on body composition, serum leptin, bone turnover, and exercise capacity. Journal of Clinical Endocrinology and Metabolism 200186 1968-1972.

7 Hunt PJ, Gurnell EM, Huppert FA, Richards C, Prevost AT, Wass JA, Herbert J \& Chatterjee VK. Improvement in mood and fatigue after dehydroepiandrosterone replacement in Addison's disease in a randomized, double blind trial. Journal of Clinical Endocrinology and Metabolism 200085 4650-4656.

8 Arlt W, Callies F, van Vlijmen JC, Koehler I, Reincke M, Bidlingmaier M, Huebler D, Oettel M, Ernst M, Schulte HM \& Allolio B. Dehydroepiandrosterone replacement in women with adrenal insufficiency. New England Journal of Medicine 1999341 1013-1020.

9 Johannsson G, Burman P, Wiren L, Engstrom BE, Nilsson AG, Ottosson M, Jonsson B, Bengtsson BA \& Karlsson FA. Low dose dehydroepiandrosterone affects behavior in hypopituitary 
androgen-deficient women: a placebo-controlled trial. Journal of Clinical Endocrinology and Metabolism 200287 2046-2052.

10 Lovas K, Gebre-Medhin G, Trovik TS, Fougner KJ, Uhlving S, Nedrebo BG, Myking OL, Kampe O \& Husebye ES. Replacement of dehydroepiandrosterone in adrenal failure: no benefit for subjective health status and sexuality in a 9-month, randomized, parallel group clinical trial. Journal of Clinical Endocrinology and Metabolism $2003 \mathbf{8 8} 1112-1118$.

11 Hangaard J, Andersen M, Grodum E, Koldkjaer O \& Hagen C. The effects of endogenous opioids and cortisol on thyrotropin and prolactin secretion in patients with Addison's disease. Journal of Clinical Endocrinology and Metabolism 199984 1595-1601.

12 Christiansen JJ, Gravholt CH, Fisker S, Svenstrup B, Bennett P, Veldhuis J, Andersen M, Christiansen JS \& Jorgensen JO. Dehydroepiandrosterone supplementation in women with adrenal failure: impact on twenty-four h GH secretion and IGF-related parameters. Clinical Endocrinology $200460461-469$.

13 Gravholt CH, Schmitz O, Simonsen L, Bulow J, Christiansen JS \& Moller N. Effects of a physiological GH pulse on interstitial glycerol in abdominal and femoral adipose tissue. American Journal of Physiology 1999277 E848-E854.

14 Jansson PA, Smith U \& Lonnroth P. Interstitial glycerol concentration measured by microdialysis in two subcutaneous regions in humans. American Journal of Physiology $1990 \mathbf{2 5 8}$ E918-E922.

15 Larsen OA, Lassen NA \& Quaade F. Blood flow through human adipose tissue determined with radioactive xenon. Acta Physiologica Scandinavica $196666337-345$.

16 Gravholt $\mathrm{CH}$, Moller N, Jensen MD, Christiansen JS \& Schmitz O. Physiological levels of glucagon do not influence lipolysis in abdominal adipose tissue as assessed by microdialysis. Journal of Clinical Endocrinology and Metabolism $2001862085-2089$.

17 Bulow J, Jelnes R, Astrup A, Madsen J \& Vilmann P. Tissue/blood partition coefficients for xenon in various adipose tissue depots in man. Scandinavian Journal of Clinical and Laboratory Investigation $1987471-3$.

18 Frayn KN. Calculation of substrate oxidation rates in vivo from gaseous exchange. Journal of Applied Physiology 198355 628-634.

19 Thompson GN, Pacy PJ, Merritt H, Ford GC, Read MA, Cheng KN \& Halliday D. Rapid measurement of whole body and forearm protein turnover using a $\left[{ }^{2} \mathrm{H}_{5}\right]$ phenylalanine model. American Journal of Physiology 1989256 E631-E639.

20 Nair KS, Ford GC, Ekberg K, Fernqvist Forbes E \& Wahren J. Protein dynamics in whole body and in splanchnic and leg tissues in type I diabetic patients. Journal of Clinical Investigation 199595 2926-2937.

21 Copeland KC \& Nair KS. Acute growth hormone effects on amino acid and lipid metabolism. Journal of Clinical Endocrinology and Metabolism $1994 \mathbf{7 8}$ 1040-1047.

22 Cleary MP \& Zisk JF. Anti-obesity effect of two different levels of dehydroepiandrosterone in lean and obese middle-aged female Zucker rats. International Journal of Obesity $1986 \mathbf{1 0}$ 193-204.

23 Frystyk J, Dinesen B \& Orskov H. Non-competitive time-resolved immunofluorometric assays for determination of human insulin-like growth factor I and II. Growth Regulation $1995 \mathbf{5}$ $169-176$.

24 Lloyd B, Burrin J, Smythe P \& Alberti KG. Enzymic fluorometric continuous-flow assays for blood glucose, lactate, pyruvate, alanine, glycerol, and 3-hydroxybutyrate. Clinical Chemistry 1978 24 1724-1729.

25 Weeke J, Boye N \& Orskov H. Ultrafiltration method for direct radioimmunoassay measurement of free thyroxine and free tri-iodothyronine in serum. Scandinavian Journal of Clinical and Laboratory Investigation 198646 381-389.

26 Lykkesfeldt G, Bennett P, Lykkesfeldt AE, Micic S, Moller S \& Svenstrup B. Abnormal androgen and oestrogen metabolism in men with steroid sulphatase deficiency and recessive X-linked ichthyosis. Clinical Endocrinology 198523 385-393.

27 Sheffield-Moore M. Androgens and the control of skeletal muscle protein synthesis. Annals of Medicine 200032 181-186.

28 Verhoeven G \& Swinnen JV. Indirect mechanisms and cascades of androgen action. Molecular and Cellular Endocrinology 1999151 205-212.

29 Gebre-Medhin G, Husebye ES, Mallmin H, Helstrom L, Berne C, Karlsson FA \& Kampe O. Oral dehydroepiandrosterone (DHEA) replacement therapy in women with Addison's disease. Clinical Endocrinology $2000 \mathbf{5 2} 775-780$.

30 Elbers JM, Asscheman H, Seidell JC \& Gooren LJ. Effects of sex steroid hormones on regional fat depots as assessed by magnetic resonance imaging in transsexuals. American Journal of Physiology 1999276 E317-E325.

31 Elbers JM, de Jong S, Teerlink T, Asscheman H, Seidell JC \& Gooren LJ. Changes in fat cell size and in vitro lipolytic activity of abdominal and gluteal adipocytes after a one-year cross-sex hormone administration in transsexuals. Metabolism $1999 \mathbf{4 8}$ $1371-1377$.

32 Sheffield-Moore M, Urban RJ, Wolf SE, Jiang J, Catlin DH, Herndon DN, Wolfe RR \& Ferrando AA. Short-term oxandrolone administration stimulates net muscle protein synthesis in young men. Journal of Clinical Endocrinology and Metabolism $1999 \mathbf{8 4}$ 2705-2711.

33 Ferrando AA, Tipton KD, Doyle D, Phillips SM, Cortiella J \& Wolfe RR. Testosterone injection stimulates net protein synthesis but not tissue amino acid transport. American Journal of Physiology 1998275 E864-E871.

34 Rasmussen BB, Volpi E, Gore DC \& Wolfe RR. Androstenedione does not stimulate muscle protein anabolism in young healthy men. Journal of Clinical Endocrinology and Metabolism $2000 \mathbf{8 5}$ 55-59.

35 Katznelson L, Finkelstein JS, Schoenfeld DA, Rosenthal DI, Anderson EJ \& Klibanski A. Increase in bone density and lean body mass during testosterone administration in men with acquired hypogonadism. Journal of Clinical Endocrinology and Metabolism $1996 \mathbf{8 1} 4358-4365$.

36 Urban RJ, Bodenburg YH, Gilkison C, Foxworth J, Coggan AR, Wolfe RR \& Ferrando A. Testosterone administration to elderly men increases skeletal muscle strength and protein synthesis. American Journal of Physiology 1995269 E820-E826.

37 Schriock ED, Buffington CK, Hubert GD, Kurtz BR, Kitabchi AE, Buster JE \& Givens JR. Divergent correlations of circulating dehydroepiandrosterone sulfate and testosterone with insulin levels and insulin receptor binding. Journal of Clinical Endocrinology and Metabolism 198866 1329-1331.

38 Paula FJ, Gouveia LM, Paccola GM, Piccinato CE, Moreira AC \& Foss MC. Androgen-related effects on peripheral glucose metabolism in women with congenital adrenal hyperplasia. Hormone and Metabolic Research $199426552-556$.

39 Buffington CK, Givens JR \& Kitabchi AE. Opposing actions of dehydroepiandrosterone and testosterone on insulin sensitivity. In vivo and in vitro studies of hyperandrogenic females. Diabetes $199140693-700$.

40 Buffington CK, Pourmotabbed G \& Kitabchi AE. Case report: amelioration of insulin resistance in diabetes with dehydroepiandrosterone. American Journal of Medical Sciences 1993306 320-324.

41 Liu D \& Dillon JS. Dehydroepiandrosterone activates endothelial cell nitric-oxide synthase by a specific plasma membrane receptor coupled to Galpha(i2,3). Journal of Biological Chemistry 2002277 21379-21388.

Received 7 July 2004

Accepted 23 September 2004 